\title{
The Nucleotide Profile of Human Milk
}

\author{
LYNN M. JANAS AND M. F. PICCIANO ${ }^{(36)}$ \\ Department of Foods and Nutrition, School of Human Resources and Family Studies, University of Illinois, Urbana, \\ Illinois, USA
}

\begin{abstract}
Summary
To further identify and characterize the nitrogen fraction of human milk, nucleotide and total nitrogen contents were determined using high pressure liquid chromatography and Kjeldahl analyses. Five lactating women were followed longitudinally. Each provided 16 milk samples $(8-10 \mathrm{ml}$ each) collected before and after a single nursing, and in the morning and afternoon of a single day. This collection scheme was followed at $2,4,8$, and 12 wk postpartum. The variance pattern of nucleotides was observed to be distinct from that of total nitrogen. As the lactation period progressed from wk 2 to 12 postpartum, levels of cytidine $5^{\prime}$ monophosphate and adenosine $5^{\prime}$ monophosphate declined from 594 to $321 \mu \mathrm{g} / 100 \mathrm{ml}$ and from 244 to $143 \mu \mathrm{g} / 100 \mathrm{ml}$, respectively, whereas levels of inosine $5^{\prime}$ monophosphate increased from 158 to $290 \mu \mathrm{g} / 100 \mathrm{ml}$ and levels of total nucleotide nitrogen remained constant. Nucleotide nitrogen accounted for approximately 0.1 $0.15 \%$ of the total nitrogen content of human milk samples analyzed. Total nitrogen concentration of human milk was observed to decrease as lactation progressed and to be higher in afternoon than in morning samples. The nucleotide profile of human milk was characteristically different from that of other milks commonly used in infant feeding. It is estimated that an infant consuming human milk as a principal nutrition source would ingest 1.4-2.1 mg of nucleotide nitrogen per day.
\end{abstract}

\section{Speculation}

Inosine $5^{\prime}$ monophosphate may contribute to the superior iron absorption of the human milk fed infant as suggested by the 2 -fold increase in human milk inosine ${ }^{\prime}$ ' monophosphate levels that were observed at a time when infant iron stores were decreasing.

Approximately $15-25 \%$ of the total nitrogen content of human milk is represented by nonprotein nitrogen $(2,17)$. The contribution of this fraction to total nitrogen content is at least three times greater in human milk than in the milk of other species used in infant feeding (19). Although the nonprotein nitrogen pool of human milk was recently analyzed for its urea, amino acid, uric acid, and ammonia contents, approximately $10 \%$ of the total nitrogen present as nonprotein nitrogen remained uncharacterized (2). Nucleotides are one class of nitrogen-containing constituents for which little information is available. Without this information, it is not possible to determine infant intakes when human milk forms the basis of the diet. At the same time, dietary nucleotides have been described as growth factors for the neonate (11), and have been implicated as agents responsible for the superior iron absorption from human milk (21). Nucleotides are extremely labile compounds and only recently, with the advent of rapid and sensitive techniques of measurement such as high pressure liquid chromatography was the methodology available for quantitative determination of these compounds in biologic samples (13).

The present study was undertaken to identify and characterize the nucleotide contents of human milk. Because the total nitrogen content of human milk has been reported to vary with stage of lactation, diurnally, and even within a single nursing period $(3,9$,
$18,20,22)$, the possibility existed that nucleotides might vary in a similar fashion. For this reason, sample collection procedures were designed to permit an evaluation of the variation patterns of nucleotides in relation to the variance patterns of total nitrogen.

\section{MATERIALS AND METHODS}

The use of human subjects in the present investigation was reviewed and approved by the Institutional Review Board at the University of Illinois, Urbana, IL in July of 1979. Written informed consent was obtained from each subject before the first sample collection. A total of $80(8-10 \mathrm{ml})$ milk samples were collected by five lactating women either by manual expression or with the aid of a small hand pump into clean plastic containers. Each mother provided a total of 16 human milk samples, four per week, collected at wk 2, 4, 8, and 12 of lactation. Each of the wkly samples were collected before and after a single nursing (fore- and hindmilk) and in the morning and afternoon of a single day. For sample collections, the infant started nursing at the breast that was second at the last feeding and a milk sample was expressed from the opposite breast. A hindmilk sample was expressed from the same breast after the infant finished nursing from it. Mothers were provided with reagent grade water ("Nanopure," Barnstead, Boston, MA) in a wash bottle for rinsing the breast pump after each sample collection. Due to nucleotide lability, samples were frozen immediately in liquid nitrogen after collection, and subsequently analyzed. For purposes of comparison, two aliquots each of fresh Holstein milk, commercially available homogenized cow milk, and formula samples ("Enfamil") were analyzed for nucleotide contents. The fresh Holstein milk analyzed was taken from a single cow (day 270 lactation), collected immediately after milking, and processed in the same manner as human milk samples.

Nucleotide analyses were performed according to the method of Hartwick and Brown (13). Samples were defrosted and $10 \mathrm{ml}$ of $0.6 \mathrm{M}$ perchloric acid were added to $5 \mathrm{ml}$ of milk and centrifuged at $17,000 \times g$ for $10 \mathrm{~min}$. The supernatant was filtered (Whatman GF/D, Clifton, $\mathrm{NJ}$ ) to remove fat and neutralized with $3 \mathrm{M}$ Potassium Hydroxide to $\mathrm{pH}$ 6-7 within $1 \mathrm{~h}$. After centrifugation, the supernatant was again frozen in liquid nitrogen, freezedried for $12 \mathrm{~h}$ and stored in a vacuum desiccator at $-20^{\circ} \mathrm{C}$. Under these conditions, nucleotides are reported to be stable for 3 months (4) and $80 \%$ recoverable (25). By adding known amounts of nucleotide standards to human milk samples and subjecting them to the above experimental procedures, comparable recoveries were established in our laboratory.

Immediately before injection on a Tracor Model \#950 high pressure liquid chromatography system (Tracor, Austin, TX), samples were reconstituted to $1 \mathrm{ml}$. Appropriate standards (Sigma, St. Louis, MO) were used to establish retention times of each nucleotide. Quantification was achieved with a Hewlett Packard Model 3380A Integrator-Recorder for peak area versus quantity of nucleotide standard injected.

Total nitrogen was determined by Kjeldahl analysis according to A.O.A.C. procedure (1). Split plot analysis of variance, least squared significant difference (LSD), and linear regression statistics were used in data evaluation (31). A value of $P<0.05$ was taken as the level of significance. 
Table 1. Mean nucleotide content of human milk at weeks 2, 4, 8, and 12 of lactation $^{(1,2)}$

\begin{tabular}{|c|c|c|c|c|c|c|}
\hline \multirow[b]{3}{*}{ Nucleotide } & \multicolumn{4}{|c|}{ Weeks } & \multicolumn{2}{|c|}{ Entire experimental period } \\
\hline & 2 & 4 & 8 & 12 & Range & Mean \\
\hline & \multicolumn{4}{|c|}{$(\mu \mathrm{g} / 100 \mathrm{ml})$} & \multicolumn{2}{|c|}{$(\mu \mathrm{g} / 100 \mathrm{ml})$} \\
\hline CMP & $594(37.8)^{3}$ & $530(41.4)$ & $418(36.9)$ & $321(27.7)$ & $147-180$ & $461(17.9)$ \\
\hline UMP & $179(41.7)$ & $258(58.8)$ & $139(19.0)$ & $141(27.1)$ & $71-1237$ & $179(19.8)$ \\
\hline AMP & $244(30.6)^{4}$ & $171(34.7)$ & $154(12.7)$ & $143(18.3)$ & $54-756$ & $175(12.8)$ \\
\hline IMP & $158(31.5)^{5}$ & $223(27.3)$ & $230(21.2)$ & $290(29.5)$ & $53-642$ & $228(14.5)$ \\
\hline GMP & $116(16.2)$ & $150(17.0)$ & $120(15.0)$ & $163(17.4)$ & $58-366$ & $138(8.5)$ \\
\hline UDP & $156(20.4)$ & $180(28.2)$ & $155(19.7)$ & $201(29.1)$ & Trace- 586 & $174(12.8)$ \\
\hline $\mathrm{CDP}$ & $389(60.4)$ & $428(87.2)$ & $607(87.0)$ & $460(107.3)$ & ND-1488 & $474(41.5)$ \\
\hline ADP & $118(68.2)$ & $83(31.8)$ & $42(11.6)$ & $41(10.5)$ & ND-487 & $69(17.9)$ \\
\hline GDP & $97(13.6)$ & $91(9.4)$ & $99(19.7)$ & $96(25.3)$ & ND-536 & $96(8.9)$ \\
\hline
\end{tabular}

\footnotetext{
${ }^{1}$ Values are expressed as Mean (S.E.).

${ }^{2} \mathrm{CMP}$, cytidine 5' monophosphate; UMP, uridine 5' monophosphate; AMP, adenosine 5' monophosphate; IMP, inosine 5' monophosphate; GMP, guanosine $5^{\prime}$ monophosphate; UDP, uridine 5' diphosphate; CDP, cytidine 5' diphosphate; ADP, adenosine 5' diphosphate; GDP, guanosine 5' diphosphate.

${ }_{3,4,5}$ Linear regression equations and significant regression coefficients $(P<0.05) ; \mathrm{CMP}, \mathrm{y}=-3.88 \mathrm{x}+641, r=0.554 ; \mathrm{AMP}, \mathrm{y}=-1.18 \mathrm{x}+231, r$ $=0.275 ; \mathrm{IMP}, \mathrm{y}=1.59 \mathrm{x}+154, r=0.338$; where $\mathrm{y}=\mu \mathrm{g} / 100 \mathrm{ml}$ of nucleotide and $\mathrm{x}=$ days postpartum.
}

\section{RESULTS}

Means and standard deviations for each of the nine nucleotides identified in human milk at wk 2, 4, 8, and 12 of lactation, and means for the entire experimental period are presented in Table I. Using split plot analysis of variance statistics, no significant differences in nucleotide contents of AM and PM milk samples or between fore- and hindmilk samples were noted. Linear regression analysis revealed significant changes in concentrations of adenosine $5^{\prime}$ monophosphate (AMP), cytidine 5' monophosphate (CMP), and inosine $5^{\prime}$ monophosphate (IMP) with the progression of lactation (Table 1). On comparing samples of wk 2 with those of wk 12, the mean concentration of AMP declined from 244 to $143 \mu \mathrm{g} / 100 \mathrm{ml}$ and that of CMP declined from 594 to $321 \mu \mathrm{g} / 100$ $\mathrm{ml}$, whereas that of IMP increased from 158 to $290 \mu \mathrm{g} / 100 \mathrm{ml}$.

In general, the variation of individual nucleotide levels in human milk samples was great among the five women sampled, and the magnitude of the variation of each nucleotide appeared relatively constant as lactation progressed. The cytidine nucleotides, cytidine 5' mono- and diphosphate (CMP and CDP) were consistently present in greater quantity than the other nucleotides. Cytidine $5^{\prime}$ monophosphate decreased while CDP tended to increase as lactation advanced. It was also observed that the nucleoside monophosphates comprised a greater portion of the total nucleotide pool than the sum of their corresponding nucleoside diphosphates due to the low levels of adenosine 5 diphosphate (ADP) and guanosine $5^{\prime}$ diphosphate (GDP). Nucleoside triphosphates were not detected and our method of analysis did not permit the detection of adenosine $3^{\prime} 5^{\prime}$ cyclic monophosphate (cAMP), since we did not use ethylenediaminetetraacetic acid to chelate magnesium (28). In eight of the human milk samples analyzed, certain nucleoside diphosphates were undetected. Those absent most often were CDP and ADP, whereas GDP was absent least often. Trends noted for individual nucleotides included elevated mean levels of both uridine $5^{\prime}$ monophosphate (UMP) and guanosine $5^{\prime}$ monophosphate (GMP) in hindmilk (303 and $152 \mu \mathrm{g} / 100 \mathrm{ml}$ ) compared to foremilk (14l and $97 \mu \mathrm{g} / 100 \mathrm{ml}$ ), and elevated levels of GMP in PM milk samples $(154 \mu \mathrm{g} / 100 \mathrm{ml})$ compared to AM samples $(123 \mu \mathrm{g} / 100 \mathrm{ml})(P<0.1)$.

Significant differences in total nitrogen concentration of human milk samples were observed among wk 2, 4, 8, and 12 milk samples using analysis of variance statistics (Table 2). There was diurnal variation in total nitrogen levels at wk 2 and 8 that was not significant, possibly due to sampling variation. The linear regression analysis of total nitrogen was highly significant $(P<$ 0.0001 ). Total nitrogen levels decreased from 231 to $156 \mathrm{mg} / 100$ $\mathrm{ml}$ from wk 2 to 12 of lactation. The concentration of total nucleotides/total nitrogen significantly increased as lactation advanced.
Table 2. Diurnal and weekly mean total nitrogen contents of human milk samples ${ }^{1}$

\begin{tabular}{clccc}
$\begin{array}{c}\text { Weeks } \\
\text { postpartum }\end{array}$ & $\begin{array}{c}\text { Weekly means } \\
(\mathrm{mg} / 100 \mathrm{ml})^{2}\end{array}$ & \multicolumn{2}{c}{$\begin{array}{c}\text { Diurnal means } \\
(\mathrm{mg} / 100 \mathrm{ml})\end{array}$} & $\begin{array}{c}\text { Range of } \\
\text { diurnal } \\
\text { means }\end{array}$ \\
\hline \multirow{2}{*}{2} & $231(9)^{\mathrm{a}, 2,3}$ & AM & $223(12)$ & $159-283$ \\
& & PM & $239(14)$ & $177-301$ \\
4 & $208(9)^{\mathrm{b}}$ & AM & $214(12)$ & $160-283$ \\
& & PM & $204(15)$ & $161-269$ \\
8 & $175(7)^{\mathrm{c}}$ & AM & $169(11)$ & $129-210$ \\
& & PM & $181(11)$ & $134-225$ \\
12 & $156(4)^{\mathrm{d}}$ & AM & $154(5)$ & $123-180$ \\
& & PM & $158(6)$ & $120-189$ \\
\hline
\end{tabular}

${ }^{1}$ Values are expressed as Mean (S.E.).

${ }^{2}$ Weekly means followed by unlike lower case letter superscripts differ at $P<0.05$.

${ }^{3}$ Linear regression equation and significant regression coefficient $(P<$ $0.0001) ; y=-1.07 \mathrm{x}+241, r=0.344$ where $\mathrm{y}=\mathrm{mg} / 100 \mathrm{ml}$ of nitrogen and $\mathrm{x}=$ days postpartum.

In the nucleotide analysis of fresh Holstein cow milk samples from day 270 of lactation, small amounts of AMP and ADP were the only nucleotides detected. Measured amounts of these two nucleotides were 111 and $38 \mu \mathrm{g} / 100 \mathrm{ml}$, respectively, along with $6.61 \mathrm{~g} / 100 \mathrm{ml}$ of orotic acid. In samples of commercially available whole cow milk and cow milk based formula, no nucleotides were detected; however, orotic acid was measured in quantities of 8.70 and $5.82 \mathrm{~g} / 100 \mathrm{ml}$, respectively.

\section{DISCUSSION}

Data from the present study clearly show that the nucleotide profile of human milk is characteristically different from other milks commonly used in infant feeding. Our method of analysis permitted the identification and quantification of nine nucleotides in human milk samples collected from wk 2 to 12 of lactation. Mean concentrations of UMP, GMP, UDP, CDP, ADP, and GDP did not significantly change with the stage of lactation. On the other hand, levels of both CMP and AMP decreased, whereas those of IMP increased during the first 3 months of lactation. Although no orotic acid was detected in human milk samples, the fresh and commercial whole cow milk and formula samples all contained relatively large quantities of orotic acid. The only nucleotides detected in the other milks used in infant feeding were AMP and ADP in fresh cow milk samples. The variation of total nucleotide content of human milk was different and distinct from that of total nitrogen content. Total nucleotide content of human 
milk did not change as lactation advanced, or vary diurnally, whereas total nitrogen content decreased as lactation advanced, and did display diurnal variation.

The cytidine and uridine nucleotides measured in the present study comprised the first and second largest fractions, respectively, of the total nucleotide content. The same relative proportions were reported by Deutsch and Nilsson (6). Although levels of CMP were lower in samples analyzed in the present study than values previously reported $(14,15)$, the levels of the other mononucleotides and of the dinucleotides were higher. The present study allowed quantitative measurement of CDP, ADP, and GDP, which were undetected by Kobata et al. (15) and Johke (14). There were no trinucleotides detected in this or earlier studies $(6,14,15)$.

Levels of AMP detected in fresh cow milk samples were close to previously reported levels in Holstein milk from late lactation, where no ADP was detected (14). In all samples of cow milk origin, large quantities of orotic acid comparable to those previously reported $(14,15)$ were present, whereas none was detected in human milk samples. Johke (14) was also unable to detect orotic acid in human milk; however, trace amounts were reported by Kobata et al. (15). Feeding high dietary levels of orotic acid to rats has been shown to cause an accumulation of liver lipids (30). Based on this observation, concern has been expressed that feeding orotic acid to infants via cow milk based formulas may produce similar alterations in liver lipid metabolism. However, Durschlag and Robinson $(7,8)$ have shown that the dietary orotic acid induced fatty liver syndrome is unique to the rat, because they were unable to produce similar liver alterations in five other species by feeding orotic acid. Furthermore, feeding the rat a level of orotic acid comparable to those fed to infants was likewise without a measurable effect.

With regard to the role of nucleotides in the diet of the neonate, it has been suggested that when dietary amino acid nitrogen is reduced, other forms of nitrogen can be utilized $(24,26,29)$. Furthermore, Gyorgy (11) has found that nucleotide supplementation to weanling rats fed low protein diets significantly improved growth rate. The incorporation of orally administered, labeled nucleotides into liver DNA and RNA has been reported to be higher in neonatal than in mature rats (16). These findings suggest that these dietary components are involved in protein synthesis in the neonatal rat. Although nucleotide nitrogen quantitated in the present investigation comprised only $0.10-0.15 \%$ of the total nitrogen pool of human milk, the theoretical nucleotide intake of a totally human milk fed infant is considerable. For example, an infant consuming $700 \mathrm{ml}$ of milk per day containing $2 \mathrm{mg} / \mathrm{ml}$ of total nitrogen would ingest approximately $1.4-2.1 \mathrm{mg}$ of nucleotide nitrogen per day. The above observations are interesting considering the satisfactory growth pattern of the human milk fed infant provided with a relatively low dietary protein intake, and may in part explain the more efficient protein utilization of the human milk fed infant compared to the formula fed infant. The effects of degradation of nucleotides in the human intestinal tract have not been studied, and consequently the role of dietary nucleotides in infant nutrition is unknown. Harms and Stirling (12) have reported a specific carrier mediated transport system of nucleosides and nucleotides into intestinal mucosal cells where it appears that ATP is split to dephosphorylated adenine nucleotides and nucleosides before absorption. The capacity of this system, like the dietary load, is small relative to the dietary load of other nutrients such as hexoses and amino acids.

Human milk is unique in its ability to promote iron absorption, and although factors responsible for this ability are unknown, it has been suggested that its inosine content may be involved (21). Inosine and its metabolites, hypoxanthine, xanthine, and uric acid have been shown to enhance iron absorption in the rat $(5,10)$. These compounds enhance the activity of intestinal xanthine oxidase, which catalyzes the direct formation of $\mathrm{Fe}^{3+}$-transferrin from $\mathrm{Fe}^{2+}$ and apotransferrin $(32,33)$ for transport to the blood, and may perform a function similar to that of ceruloplasmin in the mobilization of liver iron stores. Xanthine oxidase has been isolated and characterized in human milk $(23,34)$. Human milk inosine and xanthine oxidase may play a role in the process of iron absorption considering that there was a 2-fold increase in the concentration of human milk IMP at month 3 of lactation in the present study, corresponding to a time when infant iron stores are decreasing (27).

\section{REFERENCES AND NOTES}

1. Association of Official Analytical Chemists: Milk: Total nitrogen. Official Methods of Analysis, William Horowitz, Ed., 10th edition, p. 223 Association of Official Analytical Chemists, Washington, D.C., 1965.

2. Atkinson, S. A., Anderson, G. H., and Bryan, M. H.: Human milk: comparison of the nitrogen composition in milk from mothers of premature and full-term infants. Am. J. Clin. Nutr., 33: 811 (1980).

3. Atkinson, S. A., Bryan, M. H., and Anderson, G. H.: Human milk: difference in nitrogen concentration in milk from mothers of term and premature infants. J. Pediatr., 93(1): 67 (1978).

4. Brown, P. R.: Stability of nucleotide solutions on storage as determined by high pressure liquid chromatography. Anal. Biochem., 43: 305 (1971).

5. Cheney, B. and Finch, C. A.: Effect of inosine on iron absorption in rats. Proc. Soc. Exp. Biol. Med., 103: 37 (1960).

6. Deutsch, A. and Nilsson, R.: The acid soluble nucleotides of human milk. Z. Physiol. Chem., 321: 246 (1960).

7. Durschlag, R. P. and Robinson, J. L.: Orotic acid induced metabolic changes in the rat. J. Nutr., 110(4): 816 (1980).

8. Durschlag, R. P. and Robinson, J. L.: Species specificity in the metabolic consequences of orotic acid consumption. J. Nutr., 11014): 822 (1980).

9. Erickson, B. N., Gulick, M., Hunscher, H. A., and Macy, I. G.: Human milk studies. XV. The non-protein nitrogen constituents. J. Biol. Chem., 106: 145 (1934).

10. Faelli, A. and Esposito, G. Effect of inosine and its metabolites on intestinal iron absorption in the rat. Biochem. Pharmacol., 19: 2551 (1970).

11. Gyorgy, P.: Biochemical aspects of human milk. Am. J. Clin. Nutr., 24: 970 (1971).

12. Harms, V. and Stirling, C. E.: Transport of purine nucleotides and nucleosides by in vitro rabbit ileum. Am. J. Physiol., 223: E47 (1977).

13. Hartwick, R. A. and Brown, P. R.: The performance of microparticle chemicallybonded anion-exchange resins in the analysis of nucleotides. J. Chrom., I12: 650 (1975).

14. Johke, T.: Acid soluble nucleotides of colostrum, milk, and mammary gland. J. Biochem. (Tokyo), 54: 388 (1963).

15. Kobata, A., Suzucki, A., and Kida, M.: The acid soluble nucleotides of milk. I. Quantitative and qualitative differences in nucleotide constituents in human and cow's milk. J. Biochem. (Tokyo), 51: 277 (1962).

16. Kubota, A.: Nutritional study of nucleotide components in the milk. Acta. Paediatr. Jap., 73: 197 (1969).

17. Lonnerdal, B., Forsum, E., and Hambraeus, L.: The protein content of human milk. I. A transversal study of Swedish normal material. Nut. Rep. Int., 13(2): 125 (1976).

18. Lonnerdal, B., Forsum, E., Gebre-Medhin, M., and Hambraeus, L.: Breast milk composition in Ethiopian and Swedish mothers. II. Lactose, nitrogen, and protein content. Am. J. Clin. Nutr., 29: 1134 (1976).

19. Macy, I. G., Kelly, H. J., and Sloan, R. E.: The composition of milks. National Academy of Sciences-National Research Council Publication \#254, Washington, D.C. (1953).

20. Macy, I. G. Nims, B., Brown, M, and Hunscher, H. A: Human Milk Studies. VII. Chemical analysis of milk representative of the entire first and last halves of the nursing period. Am. J. Dis. Child., 42: 569 (1931)

21. McMillan, J. A., Oski, F. A., Lourie, G., Tomarelli, R. M., and Landaw, S. A.: Iron absorption from human milk, simulated human milk, and proprietary formulas. Pediatrics, 60(6): 896 (1977).

22. Nims, B., Macy, I. G., Brown, M., and Hunscher, H. A.: Human Milk Studies. IX. Variations in the composition of milk at four hour intervals during the day and night. Am. J. Dis. Child., 43: 828 (1932).

23. Owen, E. C. and Hytten, F. E.: Xanthine oxidase in human milk. Proc. Nutr. Soc. 19: xxviii (1960).

24. Piccou, D. and Phillips, M.: Urea metabolism in malnourished children and recovered children receiving a high or low protein diet. Am. J. Clin. Nutr., 25: 1261 (1972).

25. Riss, T. L., Zorich, N. L., Williams, M. D., and Richardson, A.: A comparison of the efficiency of nucleotide extraction by several procedures and the analysis of nucleotides from extracts of liver and isolated hepatocytes by HPLC. J. Liq. Chrom., 3(1): 133 (1980).

26. Rose, W. C.. Smith, L. C., Womack, M., and Shane, M.: The utilization of the nitrogen of ammonium salts, urea, and certain other compounds in the synthesis of non-essential amino acids in vivo. J. Biol. Chem., 181: 307 (1949).

27. Saarinen, U. M.: Need for iron supplementation in infants on prolonged breast feeding. J. Pediatr., 93(2): 177 (1978).

28. Skala, J. P., Koldovsky, O., and Hahn, P.: Cyclic nucleotides in breast milk. Am. J. Clin. Nutr., 34: 343 (1981).

29. Snyderman, S. E., Holt, Jr., L. E., Dancis, J., Roitman, E., Boyer, A., and Balis, M. E.: Unessential nitrogen: A limiting factor for human growth. J. Nutr., 78: 57 (1962).

30. Standerfer, S. B. and Handler, P.: Fatty liver induced by orotic acid feeding. Proc. Soc. Exp. Biol. Med., 90: 270 (1955).

31. Steel, R. G. D. and Torrie, J. H.: Principles and procedures of statistics. McGrawHill, New York, 1960. 
32. Topham, R. W., Woodruff, J. H., and Walker, M. C.: Purification and characterization of the intestinal promoter of $\mathrm{Fe}^{3+}$-transferrin formation. Biochem. 20: 319 (1981)

33. Topham, R. W.: Isolation of an intestinal promoter of $\mathrm{Fe}^{3+}$-transferrin formation. Biochem. Biophys. Res. Commun., 85: 1339 (1978).

34. Zikakis, J. P., Dougherty, T. M., and Biasotto, N. O.: The presence and some properties of xanthine oxidase in human milk and colostrum. J. Food Sci., 41: 1408 (1976).

35. The authors are grateful to Rose Nolan, R.N., and Larry Lane, M.D., for their support by contacting subjects, and to the mothers and infants for their participation in the study. Appreciation is also expressed to Ruth $\mathrm{N}$. Reingold for technical assistance and to Janet Buck for assistance in the collection of

\section{samples.}

36. Requests for reprints should be addressed to: M. F. Picciano, Ph.D., Department of Foods and Nutrition, School of Human Resources and Family Studies, University of Illinois, 905 South Goodwin, Urbana, IL 61801.

37. Supported by The Illinois Agricultural Experiment Station (project \#338)

38. Taken from a thesis submitted to the Graduate College at the University of lllinois by Lynn M. Janas in partial fulfillment of the requirements for an M.S. Degree in Nutrition.

39. Presented in part at the annual meeting of the American Institute of Nutrition, 1981. Fed. Proc., 40(3): 876 (1981).

40. Received for publication July 17,1981

41. Accepted for publication February 4, 1982. 